\title{
IMPACT OF CLIMATE CHANGE ON FOOD SECURITY AND HEALTH OUTCOMES IN WEST AFRICAN COUNTRIES: A COINTEGRATION ANALYSIS
}

\author{
Shingirirai Mashura \\ Faculty of Business and Sustainable Development, University of Seychelles \\ DOI: 10.46609/IJSSER.2021.v06i02.015 URL: https://doi.org/10.46609/IJSSER.2021.v06i02.015
}

\begin{abstract}
The study aims to investigate the impact of climate variables (carbon emissions, rainfall and temperature)on food security and health outcomes using time series data for the period from 1961-2015 for the 10 selected West African countries using panel econometric models with fixed effects. Food security was proxied by food production, cereal production and crop production indexes while health outcomes indicators used are life expectancy, under-five mortality and crude death rate. The results show that real Gross Domestic Product (GDP) growth and population growth are important determinants of food security and health status of a nation in West Africa. Regarding climate variables, temperature has a negative and significant impact on food security whereas the impact of rainfall is significantly positive. The effects of temperature on health outcomes negative and significant while rainfall has an insignificant effect on health outcomes. As predicted by Intergovernmental Panel on Climate Change (IPCC), West African countries will face increasing temperature and decreasing rainfall patterns, which could impact negatively on food security, reduce life expectancy, and increase percentage of undernourished people as well as mortality rates. The results have important policy implications. Policies should aim to encourage adoption of modern agricultural techniques such as irrigation, increased use extension services and growing of drought resistant crops to mitigate against the harmful effects of climate change.
\end{abstract}

\section{Introduction}

Climate change and variability as evidenced by increasing atmospheric and earth's surface temperatures, fluctuations rainfall patterns, soil erosion, frequent occurrence of extreme events such as drought and cyclones and rising sea levels are key drivers of global hunger and severe food crises. The changing nature of climate variability and extremes is negatively affecting all dimensions of food security (food availability, access, utilization and stability), as well as reinforcing other underlying causes of malnutrition related to child care and feeding, health services and environmental health (World Health Organisation (WHO), 2018). The risk of food 


\section{International Journal of Social Science and Economic Research}

ISSN: $2455-8834$

Volume:06, Issue:02 "February 2021"

insecurity and malnutrition is greater these days because livelihoods and livelihood assets, especially of the poor, are more exposed and vulnerable to changing climate variability and extremes. The increasing food insecurity in African countries will compromise the realisation of Sustainable Development Goals (SDGs), and higher prices of food, which will likely result from reduced agricultural productivity will affect those already living below the poverty datum line heavily. Through its effects on agricultural productivity, climate could have serious impact on food security and consequently human health on the continent.

The impact of climate variables on food security and health outcomes have generated debate in developing countries with weak adaptation capacity, high food insecurity and health problems. However, only few studies were conducted to provide empirical evidence impact of climate change and variability on food security and health outcomes. In Africa, the few known studies include: Eeasterling et al., 2007; Kumar and Sharma, 2011; Badolo and Kinda (2011); Demeke et al., 2011; Belloumi, 2014. To contribute to the growing debate on the impact of climate change and variations on food security and human health, this study analyses the impact of climate variables on food security and health outcomes using panel data econometric models. The study will generate policy implications that may help African countries to prepare for the potential negative effects of climate change on food security and health outcomes.

The aim of this study is to examine the impact of climate change on food security and health outcomes, using time series data for the period 1961-2015 for ten selected West African countries ${ }^{1}$. The study used food production index as a proxy for food security, and life expectancy at birth, under-five mortality and crude death rate as the measures of health outcomes. Food security and health outcomes indicators were regressed on climate variables (carbon emission, rainfall and temperature) and control variables (real GDP growth, population growth, and cultivated land under cereal). We hypothesised that increase in temperature reduces food security and worsen health outcomes whereas increase in rainfall increases food security and improves health outcomes.

\subsection{Impact of Climate Change on Food Security and Human Health}

Climate change affects food security via various channels, which include agricultural productivity, income distribution, economic growth, agricultural demand and employment opportunities (Schmidhuber and Tubiello, 2007). Climate change negatively affects crop yields, food availability and stability as well as people's economic ability to access food as prices increase due to shortages (Greg et al., 2011). In addition, Greg et al. (2011) note that food utilisation may be negatively affected by climate variability through reduction in real nutrient

${ }^{1}$ Countries include: Burkina Faso, Cameroon, Cote d'Ivoire, Gambia, Ghana, Guinea, Mali, Nigeria, Senegal and Togo 
content in the food, and it may cause several health problems (Greg et al., 2011). According to Food and Agricultural Organisation (FAO) (2008) climate change has direct impact on human health, livelihood assets, food production and distribution channels. In addition, FAO (2008) notes that there are various ways in which climate factors affected food safety, which include: changes in precipitation and temperature, frequent occurrence of extreme weather events, oceanic warming and acidification and change in contaminants' transport pathways. Tirado et al. (2010) argue that climate change may affect health outcomes via its effects on socio-economic factors that are associated with food production systems such as agriculture, livestock and fishery production, demographics and human behaviour. The above analysis shows that climate change poses serious threats to food security and health outcomes. Figure 1 below describes the links between climate change, agricultural production, food security and human health.

Figure 1: Linkages between climate change factors and food security and health outcomes

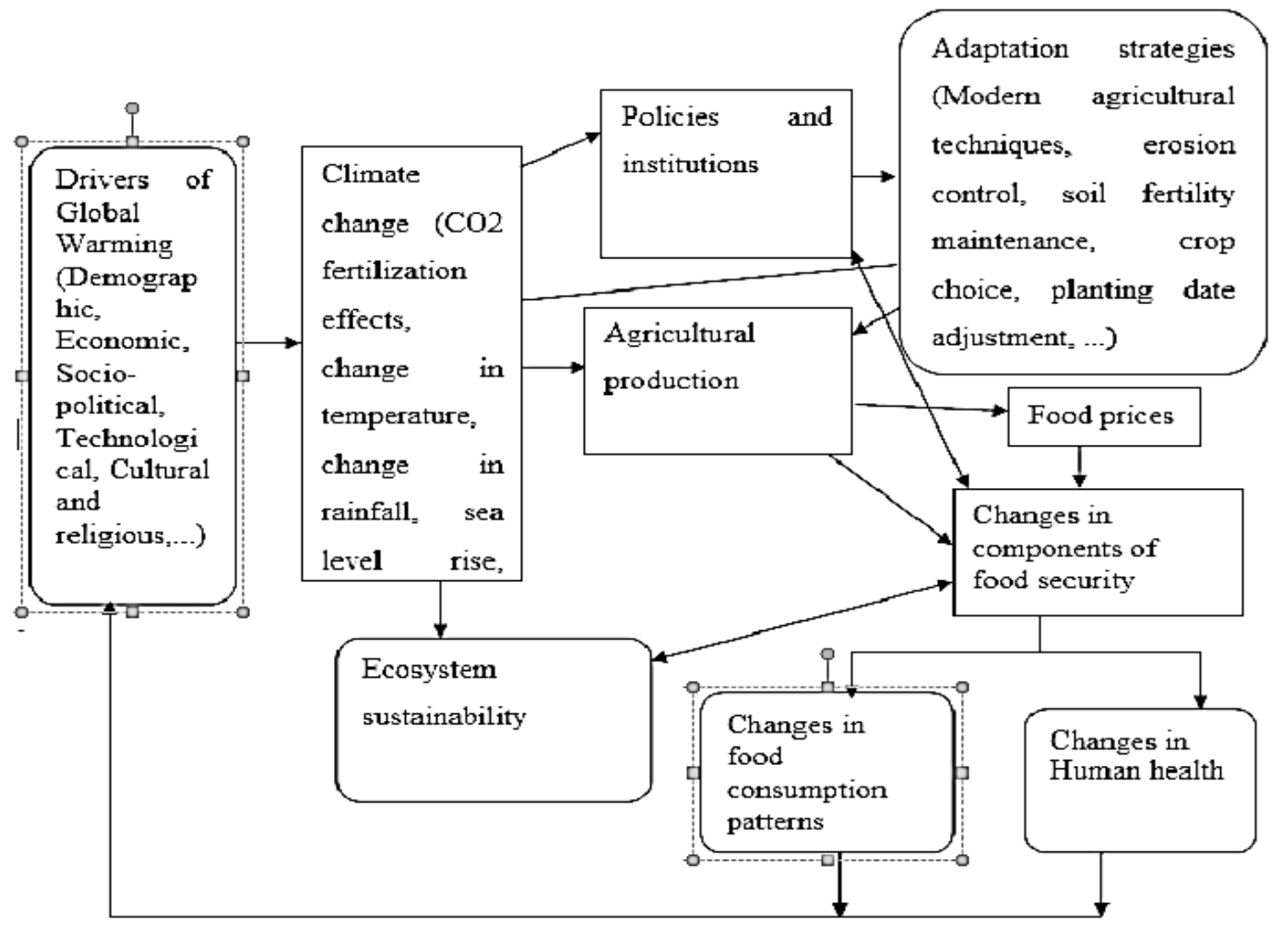

Source: Adapted from Belloumi (2014)

In Sub-Saharan Africa (SSA) cereal production will fall by 3.2 percent by the year 2050 due to climate change. Sweet potato and wheat yields are expected to be adversely impacted by climate 
change, exacerbating the problem of food security (Ringler et al., 2010). The prices of food are paramount indicator of the effects of climate change on food security; prices of cereal produce (rice, wheat and maize) in SSA are expected to be high by 2050. The high prices of cereals are likely going to dampen food demand in the region, increasing malnutrition in children (Ringler et al., 2010). The International Food Policy Research Institute (IFPRI) tries to compare calorie availability in 2050 with and without climate change and predicted it will decline resulting in an additional 24 million undernourished children (0-5 years), $21 \%$ more relative to a world with no climate change, almost half of which would be living in sub-Saharan African countries Brown, 2009). The impact of climate change on food availability in Sub-Saharan Africa is generally expected to be severe. This is primarily due to the vulnerability of subsistence farmers, who are believed to have a low capacity to cope with environmental stresses (Gregory et al., 2005).

Climate change is likely to have considerable impacts on food safety, both direct and indirect, placing public health at risk. Figure 2 below shows the direct and indirect impacts of climate change on health outcomes. 
International Journal of Social Science and Economic Research

ISSN: 2455-8834

Volume:06, Issue:02 "February 2021"

Figure 2:Impacts of climate change on human health

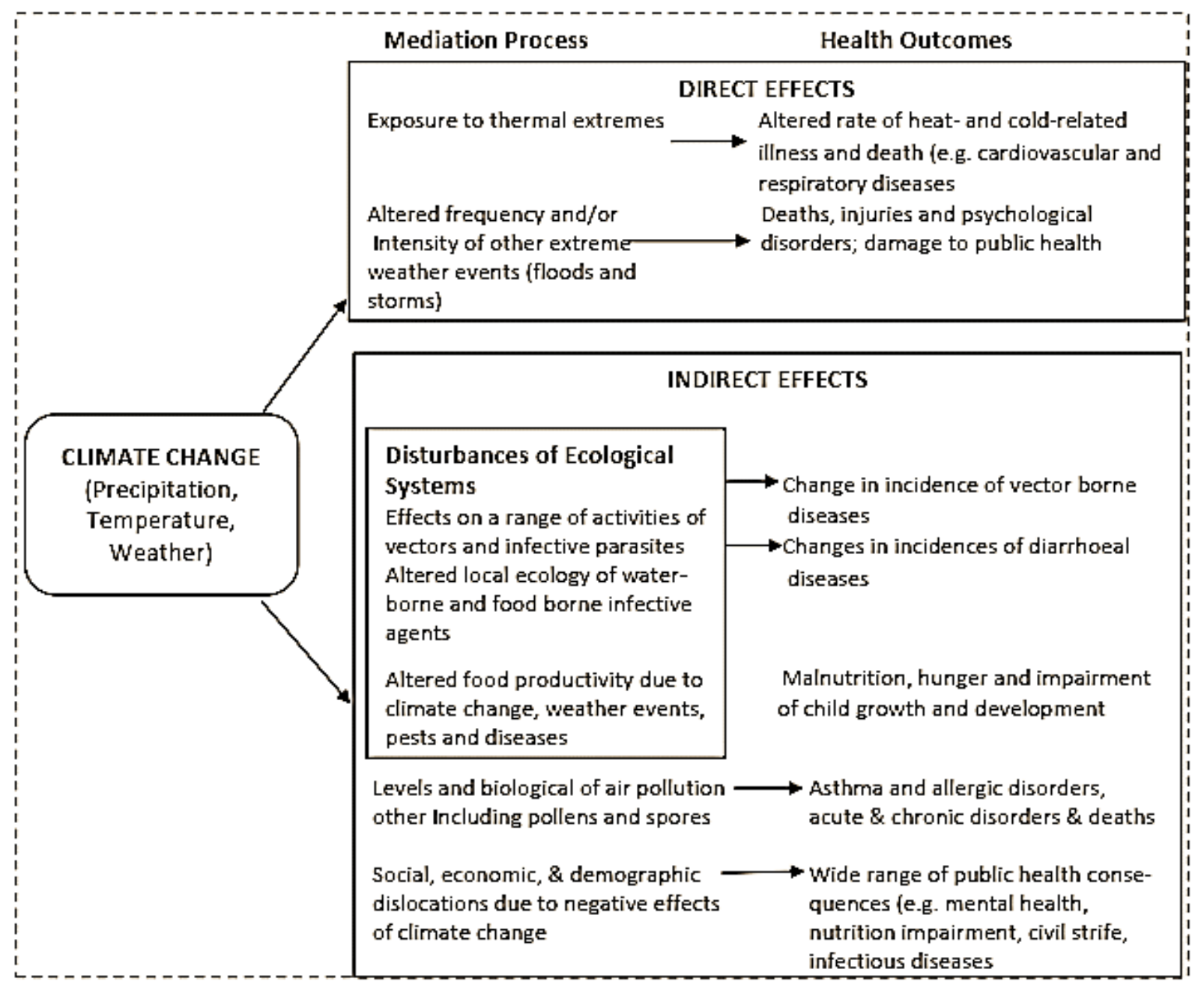

Source: Author

With changing rainfall patterns and increases in extreme weather events and the annual average temperature, impacts of climate change become evident. These impacts could possibly affect the persistence and occurrence of bacteria, viruses, parasites, harmful algae, fungi and their vectors, and the patterns of their corresponding foodborne diseases and risk of toxic contamination (WHO, 2018). Various changes driven by climate change influence behaviours which impact food safety, including: human, animal and vector behaviours, and changing pathogen, organism and pest survival, growth and transmission behaviours (Tirado et al., 2010). Such incidents are more likely to occur in African countries where food monitoring and surveillance systems are less robust, unable to detect environmental and chemical contamination, further increasing the risk to public health through the acute and chronic exposure to contaminants. 


\section{International Journal of Social Science and Economic Research}

ISSN: $2455-8834$

Volume:06, Issue:02 "February 2021"

\subsection{Econometric Model and Data}

The study analysed the impact of climate factors on food security and health outcomes from 1961-2015 for 10 selected West African countries using panel data econometric analysis. The approach is motivated by the hypothesis that changes in climate factors impact on both food production and health outcomes. Rainfall, temperature and carbon emissions are among key determinants of food insecurity which also impact directly and indirectly on human health. We estimated the model given by Badolo and Kinda (2011), Kumar and Sharma (2013) and Belloumi (2014). The model also follows the conceptual framework presented in Fig 5, which describes the linkages between climate variables and food security and health outcomes:

$$
Y_{i t}=\alpha_{i}^{0}+\alpha_{t}^{0}+\lambda X_{i t}+\beta C C_{i t}+\varepsilon_{i t}
$$

where: $Y_{i t}$ is the vector of food security (food production index, cereal production index and crop production index) and health outcome variables (mortality rate of children under the age of five, life expectancy at birth, infant mortality rate, crude death rate). $X_{i t}$ is a vector of control variables (real gross domestic per capita, population density, agriculture land under cereal production) and $C C_{i t}$ is the vector of climate variables (rainfall, temperature changes, carbon emission) in country i and time t. $\alpha_{i}^{0}$ and $\alpha_{t}^{0}$ denotes country-specific and time effects. $\varepsilon_{i t}$ is the error term while $\beta$ and $\lambda$ are the vectors of parameters to be estimated.

To be able to estimate equation 1 as well as to ensure variable uniformity among variables, the empirical model was specified in a log-liner form as follows:

$$
\begin{aligned}
& \operatorname{LnY}_{i t}=\alpha_{i}^{0}+\alpha_{t}^{0}+\lambda_{1} \operatorname{LnRGDP}_{i t}+\lambda_{2} \operatorname{LnPOPG}_{i t}+\lambda_{3} \operatorname{LnAGL}_{i t}+\beta_{1} \text { LnRain }_{i t}+\beta_{2} \text { LnTemp }_{i t} \\
& +\beta_{3} \operatorname{LnCab}_{i t}+\varepsilon_{i t}
\end{aligned}
$$

\subsection{Data}

The alternative measures of food security include: Global Hunger Index (HGI), food production index and proportion of undernourished people. Since the GHI and proportion of undernourished people has short term data, in our analysis we used food production index. Food and Agriculture Organisation (FAO) measures food production index as covering all food crops considered edible and contain nutrients. The other two measure; cereal and crop production indexes that relates to food production in a country. To measure health status, our analysis used life expectancy at birth, under five mortality and crude death rate, which are classified by World Bank as health status indicators. Life expectancy at birth shows the numbers of years a new-born infant would live throughout lifetime under the same prevailing mortality patterns. Under-five mortality rate indicates the probability per 1000 that a new-born child will die before reaching 5 years, given specific mortality rate patterns. Crude birth rate measures the annual number of 


\section{International Journal of Social Science and Economic Research}

ISSN: 2455-8834

Volume:06, Issue:02 "February 2021"

deaths per 1000 population ${ }^{2}$. Data used in the analysis came from World Development Indicators (WDI) except for rainfall and temperatures changes which came fromNational Oceanic and Atmospheric Administration (NOAA) and Food and Agriculture Organisation (FAO), respectively. Table 1 below shows variable description, data sources and descriptive statistics.

Table 1: Data sources and descriptive statistics

\begin{tabular}{|c|c|c|c|c|c|c|c|}
\hline Variable & Description & Source & $\begin{array}{l}\text { Expected } \\
\text { Sign }\end{array}$ & Mean & $\begin{array}{l}\text { Standard } \\
\text { Deviation }\end{array}$ & Maximum & Minimum \\
\hline \multicolumn{8}{|c|}{ Dependent Variables } \\
\hline $\mathrm{Y}_{1}$ & $\begin{array}{l}\text { Food Production } \\
\text { Index }\end{array}$ & WDI & & 71.4 & 29.5 & 155.3 & 22.9 \\
\hline $\mathrm{Y}_{2}$ & $\begin{array}{l}\text { Cereal Production } \\
\text { index }\end{array}$ & WDI & & 96.6 & 33.0 & 216.3 & 39.6 \\
\hline $\mathrm{Y}_{3}$ & $\begin{array}{ll}\text { Crop } & \text { Production } \\
\text { Index } & \end{array}$ & WDI & & 69.5 & 34.1 & 176.6 & 17.5 \\
\hline $\mathrm{Y}_{4}$ & $\begin{array}{l}\text { Under-five } \\
\text { mortality Rate }\end{array}$ & WDI & & 180.1 & 75.6 & 353.3 & 49.5 \\
\hline $\mathrm{Y}_{5}$ & Life Expectancy & WDI & & 50.8 & 7.7 & 66.7 & 32.3 \\
\hline $\mathrm{Y}_{6}$ & Crude Death Rate & WDI & & 15.7 & 5.8 & 31.3 & 6.1 \\
\hline \multicolumn{8}{|c|}{ Independent Variables } \\
\hline RGDP & $\begin{array}{l}\text { Real GDP Growth } \\
\text { (annual \%) }\end{array}$ & WDI & + & 2.6 & 3.7 & 21.2 & -16.3 \\
\hline POPG & $\begin{array}{l}\text { Population growth } \\
\text { (Annual \%) }\end{array}$ & WDI & - & 2.6 & 0.6 & 5.0 & 0.9 \\
\hline AGL & $\begin{array}{l}\text { Agricultural land } \\
\text { (hectares) }\end{array}$ & WDI & + & 2519076 & 4770615 & 19410000 & 40100 \\
\hline Rain & $\begin{array}{l}\text { Mean annual } \\
\text { rainfall }(\mathrm{mm})\end{array}$ & NOAA & $?$ & 82.5 & 39.4 & 175.6 & 4.0 \\
\hline Temp & $\begin{array}{l}\text { Temperature } \\
\text { Changes }\end{array}$ & FAO & $?$ & 0.4 & 0.5 & 1.8 & -0.9 \\
\hline $\mathrm{CAB}$ & Carbon emissions & WDI & $?$ & 9826.3 & 22499.0 & 106068.0 & -80.7 \\
\hline
\end{tabular}

${ }^{2}$ The definitions of life expectancy, under-five mortality and crude death rate are those of the World Bank. 
International Journal of Social Science and Economic Research

ISSN: 2455-8834

Volume:06, Issue:02 "February 2021"

Note: WDI-World Development Indicators, FAO-Food and Agriculture Organisation; NOAANational Oceanic and Atmospheric Administration

Income was measured by real GDP growth, which is the per capita income change between two successive years, adjusted for inflation. The priori expectation for real GDP is a positive influence on both food security and health outcomes. Annual population growth indicates the growth rate of population between two successive years. As noted by Malthus (1992), population growth burdens the agricultural resources, negatively impacting on agricultural and food production. Agricultural land under cereal production measures the harvested, even though other countries reported cultivated or sown areas. The increase in agricultural land under cereal production is expected to have a positive impact on food production and health outcomes. Greenhouse gas emissions result in global warming that poses environmental or climatic changes, which have significant impact on food security and health status of the population. The question then is, what is the impact of these climatic changes on food security and health status?

\subsection{Empirical Analysis}

\subsection{Stationarity and Cointegration Tests}

The use of time series data require that the integration order before determined before, that is, the number of times the variable is differenced for it to exhibit a stationarity nature of the series. Stationarity or unit root tests were conducted to ensure that the logarithmic nature of the variables achieve a unit root process using Levin, Lin \& Chu (LLC) and Im, Pesaran \&Shin (IPS) tests. The summary of the stationarity or unit root test results is presented in Table 2 below. The unit root test results show thatthis study used both stationary $I(0)$ and nonstationaryI(1) variables. The logarithms of food production index, cereal production, crop production index, and land under cereal production and carbon emissions were stationary after being differenced once. All the other series were stationary in levels.

Table 2: Summary of stationarity or unit root test results (Order of Integration)

\begin{tabular}{|l|l|l|}
\hline Series & Levin, Lin \& Chu & Im, Pesaran and Shin \\
\hline Food Production Index & $\mathrm{I}(1)$ & $\mathrm{I}(1)$ \\
\hline Cereal Production Index & $\mathrm{I}(1)$ & $\mathrm{I}(1)$ \\
\hline Crop Production Index & $\mathrm{I}(1)$ & $\mathrm{I}(1)$ \\
\hline Under 5 Mortality & $\mathrm{I}(0)$ & $\mathrm{I}(0)$ \\
\hline Life Expectancy & $\mathrm{I}(0)$ & $\mathrm{I}(0)$ \\
\hline
\end{tabular}


International Journal of Social Science and Economic Research

ISSN: 2455-8834

Volume:06, Issue:02 "February 2021"

\begin{tabular}{|l|l|l|}
\hline Crude Death & $\mathrm{I}(0)$ & $\mathrm{I}(0)$ \\
\hline Real GDP Growth & $\mathrm{I}(0)$ & $\mathrm{I}(0)$ \\
\hline Population Density & $\mathrm{I}(0)$ & $\mathrm{I}(0)$ \\
\hline Land Under Cereal & $\mathrm{I}(1)$ & $\mathrm{I}(1)$ \\
\hline Temperature & $\mathrm{I}(0)$ & $\mathrm{I}(0)$ \\
\hline Rainfall & $\mathrm{I}(0)$ & $\mathrm{I}(0)$ \\
\hline Carbon Emissions & $\mathrm{I}(1)$ & $\mathrm{I}(1)$ \\
\hline
\end{tabular}

Since the variables used in the analysis include both stationary and non-stationary series, there is need to conduct cointegration tests to determine whether there exist a long-run equilibrium among variables in equation 2. This was achieved by using the Engle-Granger cointegration test offered by Engle and Granger (1991). The authors argue that linear combinations of variables with different integration orders would not form a stationary series. The assumption of the Engle-Granger cointegration test is that if series are integrated of order 1, that is $I(1)$, they can produce residuals which exhibit a stationary process, $I(0)$. If the residuals exhibit a stationary process, there is cointegrating relationship between dependent and independent variables. To determine the properties of residuals, 6 equations (of the 6 dependent variables used) were estimated using Ordinary Least Squares (OLS) and the residuals from these estimations were tested for stationarity using LLC and IPS tests. The findings of the tests presented in Table 3 point to the evidence that there is cointegrating relationship between food security and health outcomes variables and the independent variables. This implies that the linear combinations of the dependent and independent variables in this study exhibit a stationary process, and thus there is a possibility of a long-run equilibrium convergence.

Table 3: Unit root test under Engle-Granger test for cointegration (Order of Integration)

\begin{tabular}{|l|l|l|}
\hline Residual Series from OLS & Levin, Lin \& Chu & Im, Pesaran and Shin \\
\hline Food Production Index & $\mathrm{I}(0)$ & $\mathrm{I}(0)$ \\
\hline Cereal Production Index & $\mathrm{I}(0)$ & $\mathrm{I}(0)$ \\
\hline Crop Production Index & $\mathrm{I}(0)$ & $\mathrm{I}(1)$ \\
\hline Under 5 Mortality & $\mathrm{I}(0)$ & $\mathrm{I}(0)$ \\
\hline Life Expectancy & $\mathrm{I}(0)$ & $\mathrm{I}(0)$ \\
\hline
\end{tabular}


International Journal of Social Science and Economic Research

ISSN: 2455-8834

Volume:06, Issue:02 "February 2021"

\begin{tabular}{|l|l|l|}
\hline Crude Death & $\mathrm{I}(0)$ & $\mathrm{I}(0)$ \\
\hline
\end{tabular}

To estimate the long-run elasticities, we adopted the Fully Modified OLS (FMOLS) approach by Phillips and Hansen (1990), which uses the semi-parametric correction to remove long-run correlations between cointegrating equations and innovations of stochastic regressors. The FMOLS produce asymptotically unbiased and efficient parameters, and it also allows for the estimation of full rank models, that is, those which include both $I(1)$ and $I(0)$ regressors.

\subsection{FMOLS Regression Results}

Two different specifications of equation 2 were estimated and the estimation results are presented in tables 4 and 5. Table 4 shows the results of the impact of climate variables and control variables on food security, proxied by food production index, cereal production and crop production index. Table 5 shows the empirical results of the impact of climate variables and control variables on health outcomes, measured by life expectancy at birth, under-five mortality rate and crude death rate.

We estimated two specifications of the model. The first specification considered control variables and climate factors (carbon emission, rainfall and temperature), while the second added the non-linear or quadratic terms of rainfall and temperature. The results show that the models did not suffer misspecification, thus the F-statistic also show that the models were correctly specified. The Hausman specification tests revealed that the country-level effects are fixed for all models estimated, hence the fixed effects estimation method was adopted.

\subsubsection{Results of impact of climate change on food security}

Table 4 shows the results for the impact of climate variables on food security (proxied by food production index, cereal production and crop production index). Our findings show that real GDP growth has a significant positive impact on food security across all models estimated. Real GDP growth of an economy increases food production, contributing to poverty reduction and hence elimination constraints on food availability and access (Roemer and Gugerty, 1997; Belloumi, 2014). In addition, higher purchasing power boosts the economy's investments in the food production sectors (Smith and Haddad, 2000). It is also reasonable to argue that increased developmental levels expand national food availability, accessibility and stability through expansion in food production sectors and improvement in resources available for purchasing food on both domestic and international markets.

Population growth has a significant negative impact on food security across all models. This supports the hypothesis by Malthus (1992) that population grows geometrically or exponentially while food production grows arithmetically, thus at some point the growth in population will 


\section{International Journal of Social Science and Economic Research}

ISSN: $2455-8834$

Volume:06, Issue:02 "February 2021"

outweigh the production of food causing food shortages or insecurity. These results confirm the predictions of Hall et al. (2017), that rapid population growth in Africa aggravates food insecurity and prevalent undernourishment across the continent. Agricultural land under cereal production has an insignificant and positive coefficient across all models (food, cereal and crop production).

Turning to climate variables, the estimated results indicate that carbon emission has no significant direct impact on food security. This could support the argument that developing countries emit very low levels carbon content which is insignificant compared to developed nations. Rainfall has a positive and significant coefficient in all models. The increase in rainfall positively impact agricultural productivity (crop, livestock and fishery production), which in turn impact positively on availability of food products in an economy. This finding is similar to the conclusion by Belloumi (2014) who also notes that increase in precipitation levels increase food availability and accessibility through its positive impact on agricultural productivity. However, the significant and negative coefficient of the quadratic term of rainfall indicate that rainfall has a maximum tolerant limit beyond which it can have harmful effects on cereal, crop and overall food production.

Temperature has a significant negative coefficient in both food and crop production models, while the coefficient is significant and positive for cereal production models. The negatively significant coefficient of temperature for food and crop production indexes mean that the increase in temperature levels would negatively impact on crop as well as overall food production. Ringler et al. (2010) also found that increase in temperature in Sub-Saharan African countries negatively impact on agricultural productivity, consequently reducing food availability and increasing prices of food products. For cereal production models, the coefficient of temperature is positive and significant implying that increase in temperature levels would increase productivity of cereals. This is not surprising since most of cereal production is not rainfed but depends largely on irrigation. The positive and significant coefficient of quadratic term of temperature across all models indicate that there is minimum level of temperature beyond which cereal, crop and overall food (crop, fish and livestock) production will be reduced.

Table 4: Results of the impact of climate variables on food security

\begin{tabular}{|c|c|c|c|c|c|c|}
\hline \multirow{2}{*}{ Variables } & \multicolumn{2}{|l|}{$\begin{array}{l}\text { Food } \\
\text { Index }\end{array}$} & \multicolumn{2}{|l|}{$\begin{array}{l}\text { Cereal } \\
\text { index }\end{array}$} & \multicolumn{2}{|c|}{$\begin{array}{ll}\text { Crop } & \text { Production } \\
\text { Index } & \end{array}$} \\
\hline & Model 1 & Model 2 & Model 1 & Model 2 & Model 1 & Model 2 \\
\hline Constant & $\begin{array}{l}3.21 \\
(0.353)\end{array}$ & $\begin{array}{l}-3.488^{* *} \\
(-2.303)\end{array}$ & $\begin{array}{l}12.723 * * * \\
(75.481)\end{array}$ & $\begin{array}{l}11.778 * * * \\
(44.120)\end{array}$ & $\begin{array}{l}-3.379 \\
(-0.313)\end{array}$ & $\begin{array}{l}-52.88 * * * \\
(-2.982)\end{array}$ \\
\hline
\end{tabular}


International Journal of Social Science and Economic Research

ISSN: 2455-8834

Volume:06, Issue:02 "February 2021"

\begin{tabular}{|c|c|c|c|c|c|c|}
\hline Real GDP Growth & $\begin{array}{l}1.61 * * * \\
(5.705)\end{array}$ & $\begin{array}{l}1.505 * * * \\
(5.461)\end{array}$ & $\begin{array}{l}0.031 * * * \\
(5.964)\end{array}$ & $\begin{array}{l}0.029 * * * \\
(5.680)\end{array}$ & $\begin{array}{l}1.862 * * * \\
(5.595)\end{array}$ & $\begin{array}{l}1.728 * * * \\
(5.354)\end{array}$ \\
\hline Population Growth & $\begin{array}{l}-2.47 * \\
(-1.684)\end{array}$ & $\begin{array}{l}-3.139 * * \\
(-2.168)\end{array}$ & $\begin{array}{l}-0.072 * * * \\
(-2.631)\end{array}$ & $\begin{array}{l}-0.106 * * * \\
(-3.733)\end{array}$ & $\begin{array}{l}-1.414 \\
(-0.814)\end{array}$ & $\begin{array}{l}-2.369 * \\
(-1.398)\end{array}$ \\
\hline $\begin{array}{l}\text { Land Under cereal } \\
\text { Production }\end{array}$ & $\begin{array}{l}5.06 \mathrm{E}-06 \\
(7.621)\end{array}$ & $\begin{array}{l}5.00 \mathrm{E}-06 \\
(7.723)\end{array}$ & $\begin{array}{l}1.07 \mathrm{E}-07 \\
(8.101)\end{array}$ & $\begin{array}{l}\text { 9.35E-08 } \\
(8.994)\end{array}$ & $\begin{array}{l}4.91 \mathrm{E}-06 \\
(6.264)\end{array}$ & $\begin{array}{l}\text { 4.84E-06 } \\
(6.381)\end{array}$ \\
\hline Carbon Emission & $\begin{array}{l}-0.0002 \\
(2.823)\end{array}$ & $\begin{array}{l}-0.0002 \\
(2.799)\end{array}$ & $\begin{array}{l}-1.12 \mathrm{E}-06 \\
(-0.629)\end{array}$ & $\begin{array}{l}-1.05 \mathrm{E}-06 \\
(-0.700)\end{array}$ & $\begin{array}{l}-0.002 * \\
(-1.701)\end{array}$ & $\begin{array}{l}-0.002 \\
(-1.639)\end{array}$ \\
\hline Rainfall & $\begin{array}{l}0.351 * * * \\
(3.759)\end{array}$ & $\begin{array}{l}1.279 * * * \\
(3.985)\end{array}$ & $\begin{array}{l}0.401 * * * \\
(2.396)\end{array}$ & $\begin{array}{l}0.327 * * * \\
(4.485)\end{array}$ & $\begin{array}{l}0.419 * * * \\
(3.787)\end{array}$ & $\begin{array}{l}1.621 * * * \\
(4.313)\end{array}$ \\
\hline Temperature & $\begin{array}{l}-20.09 * * * \\
(-12.85)\end{array}$ & $\begin{array}{l}-18.06^{* * * *} \\
(-4.806)\end{array}$ & $\begin{array}{l}0.638^{* * * *} \\
(15.102)\end{array}$ & $\begin{array}{l}0.505 * * * \\
(7.617)\end{array}$ & $\begin{array}{l}-34.82 * * * \\
(13.013)\end{array}$ & $\begin{array}{l}-27.16 * * * \\
(4.355)\end{array}$ \\
\hline Rainfall_Squared & - & $\begin{array}{l}-0.04 * * * \\
(-3.101)\end{array}$ & - & $\begin{array}{l}-0.134 * * * \\
(-4.412)\end{array}$ & - & $\begin{array}{l}-0.006 * * * \\
(-3.442)\end{array}$ \\
\hline Temperature_Squared & - & $\begin{array}{l}12.94 * * * \\
(3.658)\end{array}$ & - & $\begin{array}{l}0.165 * * * \\
(1.763)\end{array}$ & - & $\begin{array}{l}18.38 * * * \\
(4.435)\end{array}$ \\
\hline Time Dummies & No & Yes & No & Yes & No & Yes \\
\hline Observations & 550 & 550 & 550 & 550 & 550 & 550 \\
\hline R-Squared & 0.79 & 0.79 & 0.93 & 0.94 & 0.61 & 0.63 \\
\hline F-Test & $46.8 * * *$ & $47.9 * * *$ & $407.12 * * *$ & $469.96 * * *$ & $56.4 * * *$ & $52.6^{* * *}$ \\
\hline $\begin{array}{l}\text { Chi-Square } \\
\text { HausmanTest }\end{array}$ & - & $\begin{array}{l}187.4 \\
(0.0000)\end{array}$ & - & $\begin{array}{l}146.4 \\
(0.0000)\end{array}$ & - & $\begin{array}{l}123.27 \\
(0.0012)\end{array}$ \\
\hline
\end{tabular}

Note: $* * * ; * ; *$ represent $1 \% ; 5 \% ; 10 \%$ level of significance respectively

Numbers in parenthesis for Hausman Test and Breusch-Pagan Test are probabilities.

\subsubsection{Results of impact of climate variables on health outcomes}

Table 5 below shows the results of the impact of climate variables on health outcomes (life expectancy at birth, under-five mortality and crude death rate). Our results show that real GDP 
International Journal of Social Science and Economic Research

ISSN: 2455-8834

Volume:06, Issue:02 "February 2021"

growth has an expected positive and significant impact on life expectancy at birth. This means an increase in purchasing power contributes to the overall health of the national citizens, through access to nutritious food products and health services. These findings corroborate the results by Belloumi (2014) who also found a positive relationship between economic growth and life expectancy. As expected, real GDP growth has a negative and significant impact on under-five mortality and crude death rates, which shows that increase in developmental level of the economy result in reduced rates of under-five mortality and crude deaths. Thus, when the purchasing power of the people in an economy increases, mortality rates decreases significantly.

Table 5: Results of the Impact of Climate Variables on Health Outcomes

\begin{tabular}{|c|c|c|c|c|c|c|}
\hline \multirow[b]{2}{*}{ Variables } & \multicolumn{2}{|c|}{ Life Expectancy } & \multicolumn{2}{|c|}{ Under-five Mortality } & \multicolumn{2}{|c|}{ Crude Death Rate } \\
\hline & Model 1 & Model 2 & Model 1 & Model 2 & Model 1 & Model 2 \\
\hline Constant & $\begin{array}{l}41.2 * * * \\
(19.48)\end{array}$ & $\begin{array}{l}41.5 * * * \\
(11.52)\end{array}$ & $\begin{array}{l}287.2 * * * \\
(13.64)\end{array}$ & $\begin{array}{l}286.8^{* * * *} \\
(7.94)\end{array}$ & $\begin{array}{l}23.0 * * * \\
(14.40)\end{array}$ & $\begin{array}{l}22.5^{* * * *} \\
(8.25)\end{array}$ \\
\hline Real GDP Growth & $\begin{array}{l}0.31 * * * \\
(4.81)\end{array}$ & $\begin{array}{l}0.32 * * * \\
(4.82)\end{array}$ & $\begin{array}{l}-2.97 * * * \\
(-4.54)\end{array}$ & $\begin{array}{l}-2.99 * * * \\
(-4.54)\end{array}$ & $\begin{array}{l}-0.23 * * * \\
(-4.67)\end{array}$ & $\begin{array}{l}-0.23 * * * \\
(-4.69)\end{array}$ \\
\hline Population Growth & $\begin{array}{l}2.23 * * * \\
(7.70)\end{array}$ & $\begin{array}{l}2.58 * * * \\
(7.48)\end{array}$ & $\begin{array}{l}-20.48 * * * \\
(-6.01)\end{array}$ & $\begin{array}{l}-20.16^{* * *} \\
(-5.84)\end{array}$ & $\begin{array}{l}-2.10 * * * \\
(-8.14)\end{array}$ & $\begin{array}{l}-2.06 * * * \\
(-7.90)\end{array}$ \\
\hline $\begin{array}{l}\text { Land Under cereal } \\
\text { Production }\end{array}$ & $\begin{array}{l}1.97 \mathrm{E}-07 \\
(1.28)\end{array}$ & $\begin{array}{l}1.98 \mathrm{E}-07 \\
(1.28)\end{array}$ & $\begin{array}{l}3.96 \mathrm{E}-06 \\
(-2.56)\end{array}$ & $\begin{array}{l}-3.97 \mathrm{E}-06 \\
(-2.57)\end{array}$ & $\begin{array}{l}-2.45 \mathrm{E}-07 \\
(-2.10)\end{array}$ & $\begin{array}{l}-2.46 \mathrm{E}-07 \\
(-2.11)\end{array}$ \\
\hline Carbon Emissions & $\begin{array}{l}3.23 \mathrm{E}-06 \\
(0.15)\end{array}$ & $\begin{array}{l}\text { 4.11E-06 } \\
(0.19)\end{array}$ & $\begin{array}{l}0.0006 * * \\
(-2.96)\end{array}$ & $\begin{array}{l}0.000 \\
(-2.97)\end{array}$ & $\begin{array}{l}-8.21 \mathrm{E}-06 \\
(-0.49)\end{array}$ & $\begin{array}{l}-9.04 \mathrm{E}-06 \\
(-0.53)\end{array}$ \\
\hline Rainfall & $\begin{array}{l}0.033 \\
(1.53)\end{array}$ & $\begin{array}{l}0.041 \\
(0.54)\end{array}$ & $\begin{array}{l}-0.14 \\
(0.65)\end{array}$ & $\begin{array}{l}-0.14 * \\
(-0.18)\end{array}$ & $\begin{array}{l}-0.03 * * \\
(-1.88)\end{array}$ & $\begin{array}{l}-0.04 * * \\
(-0.73)\end{array}$ \\
\hline Temperature & $\begin{array}{l}-8.03 * * * \\
(-15.28)\end{array}$ & $\begin{array}{l}-8.68 * * * \\
(-9.70)\end{array}$ & $\begin{array}{l}81.7 * * * \\
(15.54)\end{array}$ & $\begin{array}{l}86.37 * * * \\
(9.64)\end{array}$ & $\begin{array}{l}5.86 * * * \\
(14.78)\end{array}$ & $\begin{array}{l}6.43 * * * \\
(9.51)\end{array}$ \\
\hline Rainfall Squared & - & $\begin{array}{l}4.86 \mathrm{E}-05 \\
(0.13)\end{array}$ & - & $\begin{array}{l}4.69 \mathrm{E}-05 \\
(0.012)\end{array}$ & - & $\begin{array}{l}-6.48 E-05 \\
(-0.23)\end{array}$ \\
\hline Temperature Squared & - & $\begin{array}{l}0.758 \\
(0.90)\end{array}$ & - & $\begin{array}{l}-5.41^{*} \\
(-0.64)\end{array}$ & - & $\begin{array}{l}-0.65 \\
(-1.03)\end{array}$ \\
\hline
\end{tabular}


International Journal of Social Science and Economic Research

ISSN: 2455-8834

Volume:06, Issue:02 "February 2021"

\begin{tabular}{|c|c|c|c|c|c|c|}
\hline Time Dummies & No & Yes & No & Yes & No & Yes \\
\hline Observations & 550 & 550 & 550 & 550 & 550 & 550 \\
\hline R-Squared & 0.85 & 0.85 & 0.69 & 0.69 & 0.78 & 0.78 \\
\hline F-Test & $61.7 * * *$ & $53.4 * * *$ & $60.9 * * *$ & $52.3 * * *$ & $61.2 * * *$ & $60.0 * * *$ \\
\hline $\begin{array}{l}\text { Chi-Square of } \\
\text { Hausman Test }\end{array}$ & $\begin{array}{l}27.13 \\
(0.0002)\end{array}$ & $\begin{array}{l}127.3 \\
(0.0000)\end{array}$ & $\begin{array}{l}19.35 \\
(0.0036)\end{array}$ & $\begin{array}{l}145.6 \\
(0.0000)\end{array}$ & $\begin{array}{l}30.19 \\
(0.0032)\end{array}$ & $\begin{array}{l}147.8 \\
(0.0000)\end{array}$ \\
\hline
\end{tabular}

Note: $* * * ; * * ; *$ represent $1 \% ; 5 \% ; 10 \%$ level of significance respectively

Numbers in parenthesis are t-statistics, except for Hausman Test and Breusch-Pagan Test where numbers are probabilities.

Regarding climate variables, carbon emissions seem to have an insignificant impact on health outcomes, across all models. The coefficients of rainfall in models for life expectancy and underfive mortality are insignificant. For crude death rate, rainfall has a positive and significant coefficient. The findings imply that the increase in rainfall patterns reduces crude death rate in West African countries. The coefficient for temperature has the expected sign for all health outcomes across all models. The increase in temperature will significantly reduce life expectancy and increase both under-five mortality and crude death rates. These findings corroborate the results by Belloumi (2014) who also found a negative and significant relationship between life expectancy and temperature changes. Belloumi (2014) also established that as temperature increase mortality rates increase as a number of diseases will also come with increased heat (see figure 2).

\subsection{Conclusions and Policy Implications}

The study investigated the impact of climate variables on food security and health outcomes using time series data for the period 1961-2015 for the 10 selected West African countries. Food security was proxied by food, cereal and crop production indexes whereas health outcome indicators used were life expectancy, under-five mortality and crude death rate. The results indicated that rainfall and temperature have adverse effects on both food security and health outcomes. The declining rainfall patterns coupled with rising temperature negatively impact on food production and increase the population of undernourished people, which further reduce life expectancy and increase mortality rates.

As expected in future, West African countries will experience decreasing rainfall patterns and increasing temperature levels, which will reduce food production and increasemalnutrition and mortality rates. Policymakers have to encourage adoption of modern farming techniques such as 
International Journal of Social Science and Economic Research

ISSN: 2455-8834

Volume:06, Issue:02 "February 2021"

irrigation and growing of drought resistant crops. Investing in research and development to increase varieties coupled with increased extension services could also improve agricultural productivity, food availability, access and stability. African countries should eliminate forms of protectionism, particularly intra-regional to promote food trade. Policies that seek to improve health services in the face of increasing temperatures should be prioritised. This may include scanning for cancer and respiratory problems.

\section{References}

Badolo, F. \& Kinda, S.R.(2011), "Do Climatic Shocks Matter for Food Security in Developing Countries?',Clermont-Ferrand, France: Centre d'Etudes et de Recherches sur le Développement International(CERDI).

Belloumi, M. (2014),"Investigating the Linkage Between Climate Variables and Food Security in ESA Countries”,AGRODEP Working Paper 0004

Boserup, E.(1965),The Conditions of Agricultural Growth: The Economics of Agrarian Change Under Population Pressure. London: Allen and Unwin LTD.

Brown M. E. (2009),"Markets, climate change, and food security in West Africa”,Environ Sci Technol Vol. 43, pp 8016-8020.

Demeke, A.B., Keil, A., \& Zeller, M. (2011),"Using Panel Data to Estimate the Effect of Rainfall Shock on Smallholders' Food Security and Vulnerability in Rural Ethiopia”, Climate Change, Vol. 108, pp 185- 206.

Easterling W, Aggarwal P, Batima P, Brander K, Erda L, Howden M, Kirilenko A, Morton J, Soussana J-F, Schmidhhuber J, Tubiello F. In: Climate Change 2007: Impacts, Adaptation and Vulnerability. Parry ML, Canziani OF, Palutikof JP, van der Linden PJ, Hanson CE, editors. Cambridge, UK: Cambridge Univ Press; 2007. pp 273-313.

Greg, E.E., Anam, B.E., William, M.F., \& Duru, E.J.C.(2011), “Climate Change, Food Security and Agricultural Productivity in African: Issues and Policy Directions", International Journal of Humanities and Social Science, Vol. 1, No. 21 pp 205-223.

Gregory, P.J., Ingram, J.S.I. \& Brklacich. M. (2005), “Climate change and food security”,Philos Trans $R$ Soc B 360, pp. 2139-48.

FAO (2008), "Climate change: Implications for food safety”. http://www.fao.org/food/foodsafety-quality/a-z-index/climate-change1/en/ 
International Journal of Social Science and Economic Research

ISSN: 2455-8834

Volume:06, Issue:02 "February 2021"

Hall, C., Dawson, T.P., Macdiarmid, J.I., Matthews, R.B. \& Smith, P. (2017), "The impact of population growth and climate change on food security in Africa: looking ahead to 2050", International Journal of Agricultural Sustainability, Vol. 15, No. 2 pp. 124-135

Malthus, T.R.(1992), “An Essay on the Principle of Population, (Based upon the Malthus's Second Essay). D. Winch (ed.)",Cambridge, UK: Cambridge University Press.

Merrick, T.W.(2002), "Population and Poverty: New Views on an Old Controversy",International Family Planning, Vol. 28, No. 1 pp. 41-46.

Ringler, C., Zhu, T., Cai, X., Koo, J. \& Wang, D.(2010), Climate Change Impacts on Food Security in Sub-Saharan Africa: Insights from Comprehensive Climate Change Modeling, IFPRI Research Brief, 15-20. Washington, DC: International Food Policy Research Institute.

Schmidhuber, J. \& Tubiello, F.N.(2007), “Global Food Security under Climate Change",Proceedings of the National Academy of Sciences of the United States of America, Vol. 104, No. 50 pp 581-596.

Smith, L. \& Haddad, L. (2000), "Explaining Child Malnutrition in Developing Countries: A Cross-country Analysis”, Washington, DC: International Food Policy Research Institute.

Tirado, M.C., Clarke, R., Jaykus, L.A., McQuatters-Gollopd, A. \& Franke, J.M. (2010), “Climate change and food safety: A review",Food research International Vol43, pp 1745-1765.

WHO, (2018),Food Safety, climate change and the role of WHO, Department of Food Safety and Zoonoses. 